\title{
Circadian Clock Regulation of pH in the Rabbit Retina
}

\author{
Andrey V. Dmitriev and Stuart C. Mangel \\ Department of Neurobiology, University of Alabama School of Medicine, Birmingham, Alabama 35294
}

\begin{abstract}
Although it is generally accepted that the acid-base ratio of tissue, as represented by the $\mathrm{pH}$, is strictly regulated to maintain normal function, recent studies in the mammalian nervous system have shown that neuronal activity can result in significant shifts in $\mathrm{pH}$. In the mammalian retina, many cellular phenomena, including neuronal activity, are regulated by a circadian clock. We thus investigated whether a clock regulates retinal $\mathrm{pH}$, using $\mathrm{pH}$-sensitive microelectrodes to measure the extracellular $\mathrm{pH}\left(\mathrm{pH}_{\mathrm{o}}\right)$ of the in vitro rabbit retina in the subjective day and night, that is, under conditions of constant darkness. These measurements demonstrated that a circadian clock regulates the $\mathrm{pH}_{\mathrm{o}}$ of the rabbit retina so that the $\mathrm{pH}_{\mathrm{o}}$ is lower at night than in the day. This day/night difference in retinal $\mathrm{pH}_{\mathrm{o}}$ was observed when the rabbits were maintained on a normal light/dark cycle and after they were maintained on a
\end{abstract}

light/dark cycle that was phase-delayed by $9 \mathrm{hr}$. Continuous recordings of retinal $\mathrm{pH}_{\mathrm{o}}$ around subjective dusk indicated that the change from daytime to nighttime $\mathrm{pH}_{\mathrm{o}}$ is relatively fast and suggested that the clock that regulates $\mathrm{pH}_{\mathrm{o}}$ is located in the retina. The lowest $\mathrm{pH}_{\mathrm{o}}$ recorded in the retina in both the day and night was in the vicinity of the inner segments of photoreceptor cells, supporting the idea that photoreceptors serve as the primary source of protons. The circadian-induced shift in $\mathrm{pH}_{\mathrm{o}}$ was several times greater than light-induced $\mathrm{pH}_{\circ}$ changes. These findings suggest that a circadian clock in the mammalian retina regulates retinal $\mathrm{pH}$.

Key words: protons; circadian rhythm; energetic metabolism; photoreceptors; acid-base; diurnal; mammal; ion-selective microelectrodes
Although all living tissue produces acid because of metabolic activity, it has been accepted that the acid-base ratio of tissue, as represented by the $\mathrm{pH}$, is strictly regulated to maintain normal function. In fact, a loss of control of $\mathrm{pH}$ can have devastating consequences, because a wide variety of neuronal processes from regulatory enzymes to ion channels are highly sensitive to acidbase dynamics. In the mammalian nervous system, however, recent studies have shown that neuronal activity can result in shifts in $\mathrm{pH}$ that are large enough to influence enzyme and channel functions (Chesler and Kaila, 1992). For example, in the mammalian retina, light stimulation produces changes in the $\mathrm{pH}$ of the extracellular space (Yamamoto et al., 1992).

In addition to the effects of light and dark adaptation, many cellular phenomena in the mammalian retina are now known to be regulated by a circadian clock (Reme et al., 1991; Cahill and Besharse, 1995), a type of biological oscillator that is intrinsic to neural tissue and has persistent rhythmicity with a period of $\sim 24$ hr in the absence of external timing cues (e.g., constant darkness) (Block et al., 1993). For example, in the mammalian retina, a circadian clock regulates dopamine content (Wirz-Justice et al., 1984), melatonin production and release (Tosini and Menaker, 1996), photoreceptor disk shedding (La Vail and Ward, 1978), and neuronal light responses (Mangel and Wang, 1997). Because neuronal activity in the mammalian retina is regulated by a circadian clock, we thus investigated whether a circadian clock regulates the $\mathrm{pH}$ of the rabbit retina. Our findings suggest that a

Received July 31, 2000; revised Jan. 16, 2001; accepted Jan. 29, 2001.

This work was supported in part by National Institutes of Health Grant EY05102 and National Science Foundation Grant IBN-9819981 to S.C.M., and by National Eye Institute CORE Grant P30 EY03039 to the University of Alabama at Birmingham. We thank Dr. Christophe Ribelayga for helpf ul discussions.

Correspondence should be addressed to Dr. Stuart Mangel, Department of Neurobiology, University of Alabama School of Medicine, 1719 Sixth Avenue South, Birmingham, AL 35294. E-mail: mangel@nrc.uab.edu.

Copyright (C) 2001 Society for Neuroscience 0270-6474/01/212897-06\$15.00/0 circadian clock in the mammalian retina regulates retinal $\mathrm{pH}$. Thus, an intrinsic oscillator in neural tissue modulates metabolic activity and $\mathrm{pH}$ as part of normal daily function.

\section{MATERIALS AND METHODS}

Experiments were performed on superfused retinas obtained from pigmented adult rabbits weighing $2.0-4.0 \mathrm{~kg}$. The rabbits were maintained for at least $10 \mathrm{~d}$ on a $12 \mathrm{hr}$ light/dark cycle or a similar cycle that had been phase-delayed by 9 hr (Fig. 2). That is, "lights on" occurred at 5 A.M. in most of the experiments but at 2 P.M. in some experiments (Fig. 2). The rabbits were then kept in constant darkness for at least $24 \mathrm{hr}$ before an experiment; all experiments were conducted during the second circadian cycle of constant darkness. The care and use of the rabbits were in accordance with federal and institutional guidelines. The rabbits were deeply anesthetized with urethane $(1.5 \mathrm{gm} / \mathrm{kg}$, i.p.), and an eye was enucleated after additional local intraorbital injections of $2 \%$ xylocaine. Surgery was performed under dim red illumination. Isolated eyecups were placed in a superfusion chamber, vitreal side up, and superfused in the dark for up to $4 \mathrm{hr}$ at $35.5-36.0^{\circ} \mathrm{C}$. The superfusion solution was made according to the formula of Ames and Nesbett (1981), including organics and amino acids but excluding horse serum. The superfusate flowed by gravity at $\sim 3 \mathrm{ml} / \mathrm{min}$ and was constantly bubbled by a gas mixture of $\mathrm{CO}_{2}$ and $\mathrm{O}_{2}$. The proportion of the gases was adjusted so that the warmed solution in the experimental chamber had a $\mathrm{pH}$ of 7.8.

Extracellular $\mathrm{pH}\left(\mathrm{pH}_{\mathrm{o}}\right)$ in the retina was measured with doublebarreled $\mathrm{pH}$-selective microelectrodes based on the Hydrogen Ionophore I-Cocktail B (Fluka, Buchs, Switzerland). The microelectrodes were constructed using a modified version of a procedure described previously (Dmitriev et al., 1999b; Dmitriev and Mangel, 2000). Briefly, the microelectrodes were pulled from borosilicate "theta" glass capillaries (WPI, Sarasota, FL). After the glass was pulled, the reference electrode barrel was backfilled with distilled water. Several micropipettes were exposed overnight to a silane atmosphere obtained by dropping $0.4-0.5 \mathrm{ml}$ of a solution of dimethyldichlorosilane in carbon tetrachloride $(10 \%$ in volume, both from Sigma, St. Louis, MO) in a tightly closed jar at room temperature. After silanization, the ion-selective barrel was backfilled with $0.5 \mu \mathrm{l}$ of the Fluka mixture. The tip of the microelectrode was broken gently on a piece of soft paper, thus allowing the ion exchanger to move spontaneously to the tip of the microelectrode. Finally, the distilled water in the reference barrel was replaced by backfilling it with 
Subjective

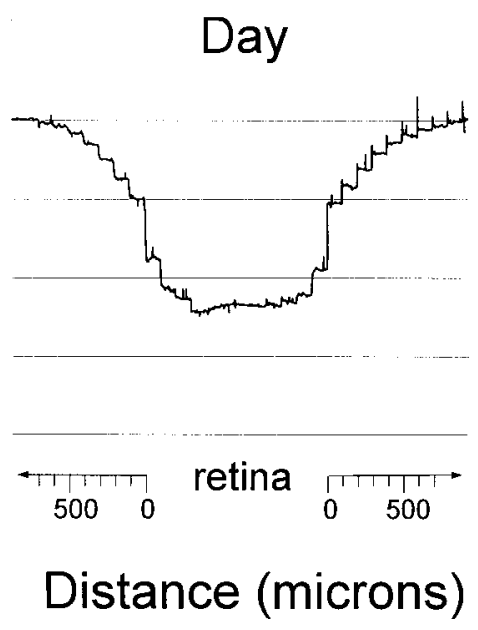

Subjective
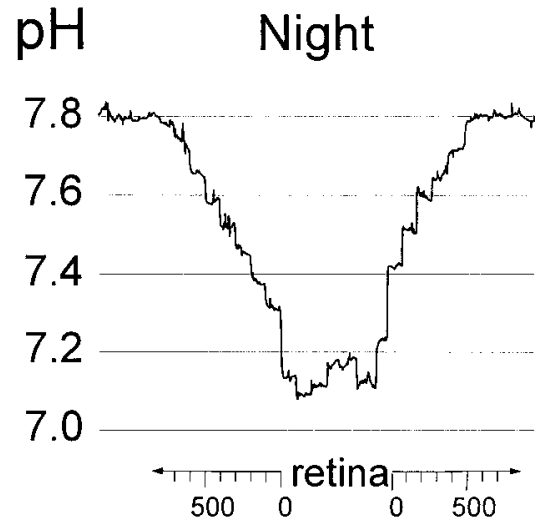

Distance (microns)
Figure 1. Extracellular $\mathrm{pH}$ of the rabbit retina is lower in the subjective night, compared with the subjective day. $\mathrm{pH}_{\mathrm{o}}$ was measured as a function of distance (micrometers) from a superfused rabbit retina in the subjective day and night. $\mathrm{pH}$ sensitive microelectrodes were advanced through the superfusate to the retina, then through the retina, and finally withdrawn. Retinal $\mathrm{pH}_{\circ}$ was always lower than superfusate $\mathrm{pH}$, and the difference between retinal and superfusate $\mathrm{pH}$ was larger in the subjective night than in the subjective day. The electrodes were moved in $100 \mu \mathrm{m}$ steps every $30 \mathrm{sec}$. Fast "spikes" on the records are movement artifacts.

\begin{abstract}
placed in the superfusate above the retina and moved toward the tissue in $100 \mu \mathrm{m}$ steps. After recording $\mathrm{pH}_{\mathrm{o}}$ in the various layers of the retina, we withdrew the $\mathrm{pH}$-sensitive microelectrodes from the retina in a series of $100 \mu \mathrm{m}$ steps. When the $\mathrm{pH}$ electrodes were within $600-800 \mu \mathrm{m}$ of the vitreal surface of the retina, the $\mathrm{pH}$ of the superfusion solution began to decrease because of the influence of the tissue. The closer the microelectrodes were to the retina, the lower the recorded $\mathrm{pH}$. In all of the experiments, a clear $\mathrm{pH}$ gradient was recorded in the solution above the retina (Fig. 1). Thus, retinal $\mathrm{pH}_{\mathrm{o}}$ was always lower than the $\mathrm{pH}$ of the superfusate. This difference in $\mathrm{pH}$ between the retina and the superfusate was a fundamental characteristic of viable tissue; when the retina lost its ability to respond to light, the $\mathrm{pH}$ difference was much smaller.

The magnitude of the $\mathrm{pH}$ difference between the retina and the superfusate depended on the time of day (Figs. 1, 2). During the subjective day [Zeitgeber Time (ZT) 7-10, where ZT 0 is dawn], the average difference between retinal $\mathrm{pH}_{\mathrm{o}}$ and superfusate $\mathrm{pH}$ was $0.47 \pm 0.03(\mathrm{SEM})(n=11)$. In contrast, during the subjective night (ZT 15-18), the average difference between retinal $\mathrm{pH}_{\mathrm{o}}$ and superfusate $\mathrm{pH}$ was $0.61 \pm 0.04(n=9 ; p<0.01)$. A similar day/night difference was obtained after the light/dark cycle was phase-delayed by $9 \mathrm{hr}$ for a period of 1 week. As shown in Figure 2 , the phase-shifted retinas exhibited a difference in retinal and superfusate $\mathrm{pH}$ of $0.48 \pm 0.03(n=8)$ during the subjective day and $0.63 \pm 0.03(n=8)$ during the subjective night $(p<0.01)$. These data thus clearly indicate that a circadian clock regulates $\mathrm{pH}_{\mathrm{o}}$ in the rabbit retina so that more acid is produced at night than in the day.

Retinal $\mathrm{pH}_{\mathrm{o}}$ varies with retinal layer in both the day and night and is lowest in the vicinity of the outer limiting membrane (OLM), a structure in the retina located in the vicinity of the inner segments of photoreceptor cells. During penetration of the retina from the vitreal side, $\mathrm{pH}_{\mathrm{o}}$ decreased until it reached a minimum value at the OLM, after which it increased slightly as the microelectrode approached the retinal pigment epithelium (Fig. 3). The $\mathrm{pH}_{\mathrm{o}}$ gradient across the retina was $13.7 \pm 1.3 \%(n=$ 8 ) of the total difference between the minimal retinal $\mathrm{pH}_{\mathrm{o}}$ and the superfusate $\mathrm{pH}$. There was no statistically significant day/night difference in the magnitude of the transretinal $\mathrm{pH}_{\mathrm{o}}$ gradient or inthe portion of transretinal $\mathrm{pH}_{\mathrm{o}}$ gradient in the total $\mathrm{pH}$ difference between retina and superfusate $(14.5 \pm 2.1 \%, n=4$ during

\section{RESULTS}

The $\mathrm{pH}_{\mathrm{o}}$ of the rabbit retina was measured with $\mathrm{pH}$-sensitive microelectrodes in the subjective day and night, that is, under conditions of constant darkness (Fig. 1). The electrodes were

a solution containing (in $\mathrm{mm}$ ): $140.0 \mathrm{NaCl}, 5.0 \mathrm{KCl}, 2.0 \mathrm{CaCl}_{2}$, and 5.0
Tris, $\mathrm{pH}$ 7.5. The same solution was also used to fill the remainder of the ion-selective barrel. Microelectrodes that were used for the experiments The resistance of the pH-selective barrel was 5-10 G $\Omega$, whereas the the diameter of the tip. Microelectrodes were calibrated in the experitissue. The calibration solutions contained the same concentrations of After software (Axon Instruments). An the dark for $1 \mathrm{hr}$ before $\mathrm{pH}$ measurements were obtained. Th $\mu \mathrm{W} / \mathrm{cm}^{2}$. Intensity values indicated in the text are relative to $I_{0}$ avelength.

The Kolmogorov-Smirnov two-sample test was used for all statistical comparisons between control and experimental conditions.
\end{abstract}




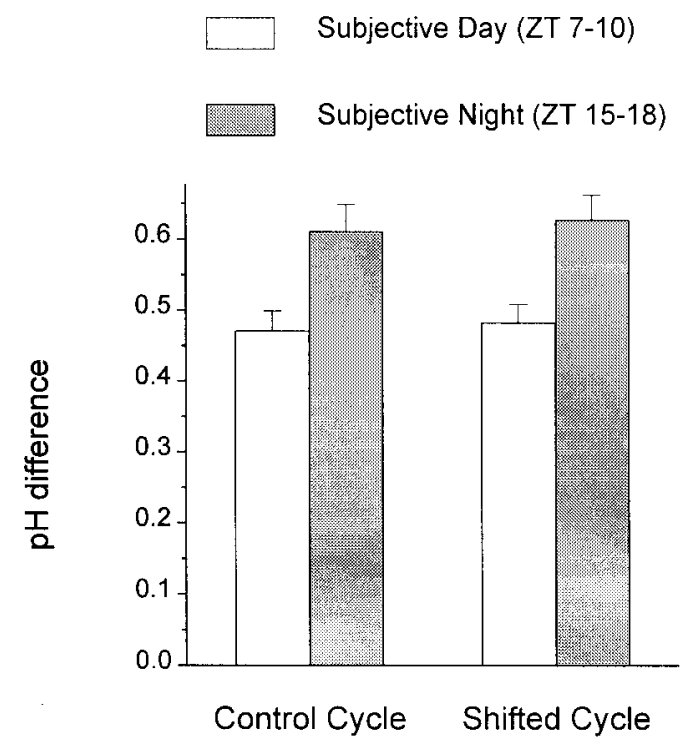

Figure 2. The average difference between retinal and superfusate $\mathrm{pH}$ exhibits a circadian rhythm. Before an experiment, the rabbits were entrained for at least $10 \mathrm{~d}$ to a $12 \mathrm{hr}$ light/dark cycle or a $12 \mathrm{hr}$ light/dark cycle that had been phase-delayed by $9 \mathrm{hr}$. At the start of an experiment, the rabbits were placed in constant darkness for at least $24 \mathrm{hr}$, after which the retinas were prepared in either the subjective day or night. The time of subjective day $(Z T 7-10)$ or night $(Z T$ 15-18) that is indicated corresponds to the time that $\mathrm{pH}$ measurements were made. Retinal $\mathrm{pH}_{\mathrm{o}}$ was defined as the lowest measured $\mathrm{pH}_{\mathrm{o}}$ in the retina. Each data point represents mean value \pm SEM for 7-12 measurements.

subjective day; and $12.9 \pm 1.5 \%, n=4$ during subjective night). In addition, the general character of the transretinal $\mathrm{pH}_{\mathrm{o}}$ gradient was also similar in the night and day. After penetration of the inner limiting membrane (ILM), a structure located at the vitreal surface of the retina, recorded $\mathrm{pH}_{\mathrm{o}}$ decreased monotonically as the $\mathrm{pH}$-selective microelectrode moved deeper into the retina in $30 \mu \mathrm{m}$ steps until it reached a minimum at the OLM. Because $\mathrm{pH}_{\mathrm{o}}$ was lowest at the OLM, photoreceptor cells are likely the primary source of acid production in the retina.

The circadian clock that modulates retinal $\mathrm{pH}_{\mathrm{o}}$ is probably located in the retina itself. Because $\mathrm{pH}_{\mathrm{o}}$ can be measured continuously with $\mathrm{pH}$-selective microelectrodes, the time course of clock-induced changes in retinal $\mathrm{pH}_{\mathrm{o}}$ could be determined accurately. These experiments indicated that $\mathrm{pH}_{\mathrm{o}}$ in the in vitro rabbit eyecup decreased at dusk but remained relatively constant during the subjective day and night. Specifically, in these experiments, $\mathrm{pH}$-selective microelectrodes were moved into the retina to the depth of the OLM during the second circadian cycle of constant darkness. The microelectrodes were then left there for $\sim 2 \mathrm{hr}$ to monitor changes in $\mathrm{pH}_{\mathrm{o}}$ before and after ZT 12 (Fig. $4 a$ ), that is, at the time of subjective dusk, or during the subjective day (ZT 7-10) or night (ZT 14-18) (Fig. 4b). As shown in Figure 4a, retinal $\mathrm{pH}_{\mathrm{o}}$ remained at approximately the same level between ZT 11 and 12 but decreased relatively quickly between ZT 12 and 13 , that is, at the start of subjective night. Moreover, the magnitude of the average change in $\mathrm{pH}_{\mathrm{o}}$ between $\mathrm{ZT} 12$ and 13 was $0.13 \pm 0.02(n=4)$, which is similar to the total day/night difference in $\mathrm{pH}_{\mathrm{o}}(0.14-0.15 \mathrm{pH}$ units $)$ described above. Although retinal $\mathrm{pH}_{\mathrm{o}}$ decreased during the transition from subjective day to subjective night at dusk, it was relatively stable when it was measured at other, nontransition times during the subjective day (ZT 7-10) and night (ZT 14-18). For example, Figure 4b

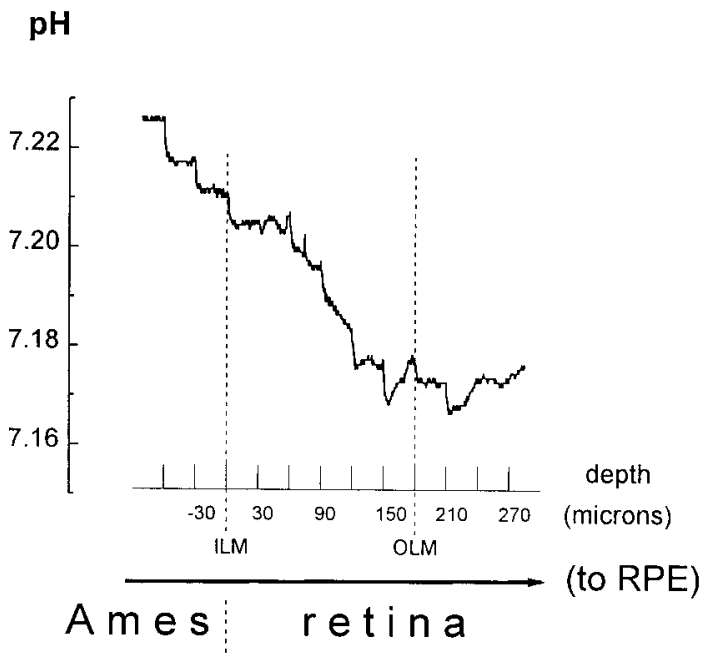

Figure 3. Retinal $\mathrm{pH}_{\mathrm{o}}$ varies with retinal depth. Depth profiles of retinal $\mathrm{pH}_{\mathrm{o}}$ were obtained with $\mathrm{pH}$-selective microelectrodes that were advanced through the superfusate (Ames medium) and retina to the retinal pigment epithelium (to $R P E$ ) in $30 \mu \mathrm{m}$ steps every $30 \mathrm{sec}$. Retinal $\mathrm{pH}_{\mathrm{o}}$ was lowest in the vicinity of the outer limiting membrane (OLM). The vitreal surface of the retina was defined as a position of 0 . The two vertical dashed lines indicate the depth at which the microelectrode penetrated the inner limiting membrane (ILM) and $O L M$. pH values are shown on the $y$-axis. Because the retina is a metabolically active tissue that produces acid, there is a $\mathrm{pH}$ gradient in its vicinity. When the $\mathrm{pH}$-selective microelectrode was at a distance of $600 \mu \mathrm{m}$ or more from the retina, the recorded $\mathrm{pH}_{\mathrm{o}}$ was 7.80 (Fig. 1). When the $\mathrm{pH}$ electrode was closer to the retinal surface, as shown in Figure 3, the $\mathrm{pH}_{\mathrm{o}}$ recorded in the Ames medium was $<7.80$

illustrates that when $\mathrm{pH}_{\mathrm{o}}$ was monitored continuously during the subjective night, beginning at $\mathrm{ZT} 14$, the $\mathrm{pH}_{\mathrm{o}}$ increased by 0.02 $\mathrm{pH}$ units over the course of $\sim 2 \mathrm{hr}$. In addition, repeated measurements of retinal $\mathrm{pH}_{\mathrm{o}}$, which were separated in time by $20-60$ min, demonstrated that retinal $\mathrm{pH}_{\mathrm{o}}$ increased slightly on average $(0.01 \mathrm{pH}$ units/hr) when it was measured during these nontransition times (ZT 7-10, $n=12$; ZT $14-18, n=13$ ). This small increase in retinal $\mathrm{pH}_{\mathrm{o}}$, which was observed during nontransition times in the subjective day and night, is probably caused by a slow decrease in the viability of the in vitro eyecup preparation with time. These results thus suggest that a circadian clock in the mammalian retina modulates retinal $\mathrm{pH}_{\mathrm{o}}$.

Although light stimulation modulates retinal $\mathrm{pH}_{\mathrm{o}}$ (Borgula et al., 1989; Oakley and Wen, 1989; Yamamoto et al., 1992), circadian-induced changes in retinal $\mathrm{pH}_{\mathrm{o}}$ are several times greater than light-induced changes, and unlike light-evoked $\mathrm{pH}$ changes, the polarity of the circadian-induced $\mathrm{pH}$ change does not depend on retinal depth. As shown in Figure 5, light stimulation produced changes in $\mathrm{pH}_{\mathrm{o}}$ of $\sim 0.01-0.02 \mathrm{pH}$ units. In the proximal (inner nuclear layer) retina, a $10 \mathrm{sec}$ light flash produced a slight alkalinization. When stimulus duration was increased (60 $\mathrm{sec}$ ), the initial alkalinization was followed by a slow acidification. In the distal retina (photoreceptor layer), the initial alkalinization was smaller and sometimes hardly visible. The delayed acidification was more prominent in the distal, compared with the proximal, retina. In the distal retina, the acidification had a very slow time course, requiring $\sim 3$ min of light stimulation to produce a maximal response (Fig. 5). Finally, no obvious difference in the effect of light stimulation on $\mathrm{pH}_{\mathrm{o}}$ was observed in the day, compared with the night. 
a

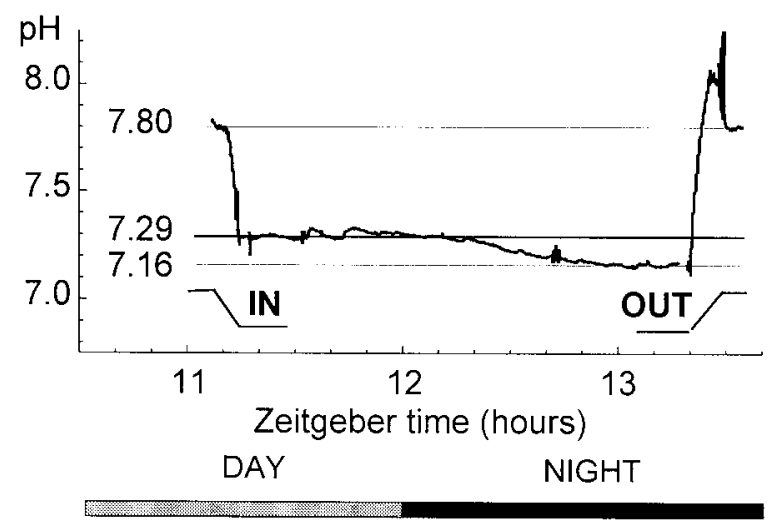

b

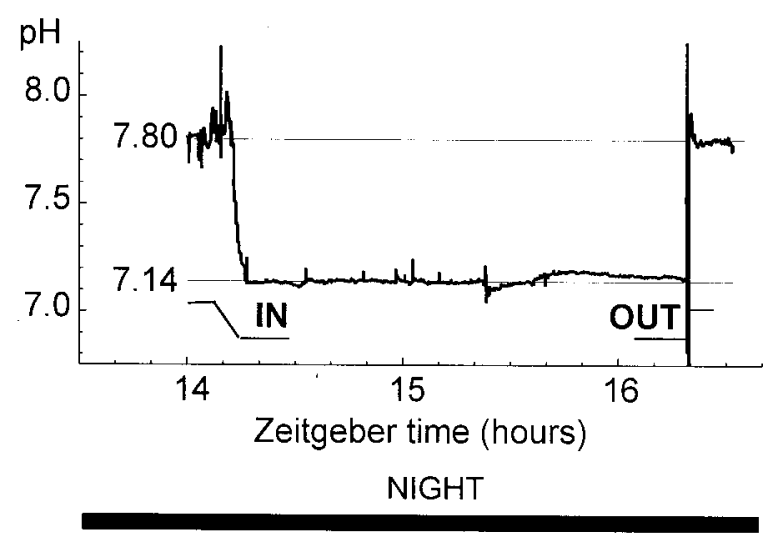

Figure 4. A circadian clock in the rabbit retina regulates retinal pH. $a$, Extracellular $\mathrm{pH}$ was monitored continuously from $1 \mathrm{hr}$ before subjective dusk (ZT 12) until $1 \mathrm{hr}$ after by placing microelectrodes into the in vitro retina at the level of the OLM. Retinal $\mathrm{pH}_{\mathrm{o}}$ decreased from a maximum (7.29) at ZT 12 to a minimum (7.16) at ZT 13. b. In contrast to the transition between subjective day and night at dusk, retinal $\mathrm{pH}_{\mathrm{o}}$ increased by $0.02 \mathrm{pH}$ units over the course of $2 \mathrm{hr}$ when it was measured during the subjective night (ZT 14-18), that is, at a nontransition time. Before and after penetration of the in vitro retina, the microelectrodes were moved to the superfusate, $\mathrm{pH} 7.8$.

\section{DISCUSSION}

The results of this study indicate that a circadian clock regulates rabbit retinal $\mathrm{pH}_{\mathrm{o}}$ so that it is lower in the night, compared with the day. The lowest $\mathrm{pH}_{\mathrm{o}}$ recorded in the retina in both the day and night was in the vicinity of the inner segments of photoreceptor cells, supporting the idea that photoreceptor cells are the principal consumers of energy in the retina and, as a consequence, serve as the primary source of protons. In addition, the clock-induced shift in $\mathrm{pH}_{\mathrm{o}}$ is several times greater than lightinduced $\mathrm{pH}_{\mathrm{o}}$ changes. Moreover, the findings suggest that the clock that modulates retinal $\mathrm{pH}_{\mathrm{o}}$ is located in the rabbit retina itself. These findings are discussed in more detail below with respect to the circadian phenomenon itself and how it might affect retinal function.

Relationship of the clock, $\mathrm{pH}$, and energetic metabolism

Although shifts in $\mathrm{pH}_{\mathrm{o}}$ attributable to neuronal activity have been reported in studies of in vitro CNS tissue (Kraig et al., 1983;

\section{proximal retina}
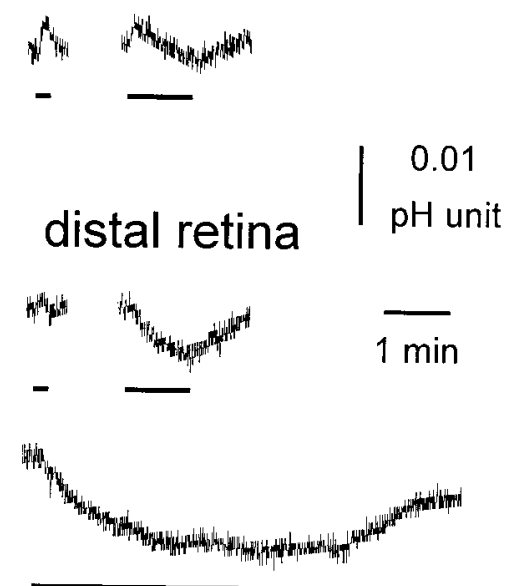

Figure 5. Light-evoked $\mathrm{pH}_{\mathrm{o}}$ changes are smaller than clock-induced changes, and the polarity of light-evoked changes in $\mathrm{pH}_{\mathrm{o}}$ depends on retinal depth. A decrease in $\mathrm{pH}_{\mathrm{o}}$ is indicated by a downward movement of the trace. Typical light-evoked changes in retinal $\mathrm{pH}$ are shown for the proximal retina (inner nuclear layer) and distal retina (photoreceptor layer). Light stimulation altered retinal $\mathrm{pH}_{\mathrm{o}}$ by $0.01-0.02 \mathrm{pH}$ units. In the proximal retina, light flashes produced an initial acidification followed by an alkalinization. In the distal retina, light flashes produced an alkalinization. Bars under the records indicate the occurrence of monochromatic $(550 \mathrm{~nm})$ light flashes $\left(-3.6 \log I_{\mathrm{o}}\right)$.

Chesler and Kaila, 1992), the current findings are the first demonstration that $\mathrm{pH}_{\mathrm{o}}$ in the mammalian CNS can be modulated by a circadian clock, an endogenous neural process. Moreover, the fact that an endogenous process produces acid in the retina suggests that the circadian-induced changes in $\mathrm{pH}_{\mathrm{o}}$ observed in the in vitro rabbit retina also occur in vivo. In fact, in support of this idea, Kraig et al. (1983) have shown that stimulus-induced shifts in the $\mathrm{pH}_{\mathrm{o}}$ of rat cortex occur to a similar extent both in vivo and in vitro, suggesting that changes in blood flow in vivo do not alter or eliminate activity-dependent and circadian clock-induced $\mathrm{pH}_{\mathrm{o}}$ shifts.

The finding that the clock decreases retinal $\mathrm{pH}_{\mathrm{o}}$ at night indicates that the clock increases the production of acid in the retina at night in a sustained manner over the course of many hours. Such a sustained increase in acid production at night is most likely caused by an increase in energetic metabolism at night, and in fact, such an increase has been demonstrated recently (Dmitriev et al., 1999a). It is well known that energetic metabolism is a proton-producing process (Krebs et al., 1975; Alberti and Cuthbert, 1982), and there is no other known sustained source of acid in the brain. This metabolic source is powerful enough to generate $\mathrm{pH}$ gradients that can be measured. During oxidative degradation of glucose, in which one $\mathrm{CO}_{2}$ molecule is released for six ATP molecules, brain tissues consume 1.5-5.0 $\mu \mathrm{M} \mathrm{O}_{2}$ each minute (Mellergard and Siesjo, 1998) and produce an equivalent amount of $\mathrm{CO}_{2}$. The acidic cost of energetic metabolism during glycolysis, when one lactic acid molecule is released for each ATP molecule made, is even higher. Thus, both the sustained difference in $\mathrm{pH}$ between retina and superfusate that is present in the day and the even greater difference in $\mathrm{pH}$ between retina and superfusate that is present at night are likely to be caused by energetic metabolic processes.

In contrast to the sustained production of acid by energetic 
metabolic processes, changes in acid-base transport, for example, probably cannot account for the sustained decrease in $\mathrm{pH}_{\mathrm{o}}$ that occurs at night. Although changes in acid-base transport can alter $\mathrm{pH}_{\mathrm{o}}$ in a transient fashion, a sustained change in acid-base transport that lasted many hours would result in substantial depletion of intracellular acid, leading to neuronal dysfunction. In contrast to clock-induced changes in $\mathrm{pH}_{\mathrm{o}}$, light-evoked changes in $\mathrm{pH}_{\mathrm{o}}$, which are much smaller in size and more transient, species dependent, and often of mixed polarity (Fig. 5) (Borgula et al., 1989; Oakley and Wen, 1989; Yamamoto et al., 1992; Dmitriev and Mangel, 2000), might be caused by changes in acid-base transport or carbonic anhydrase activity.

The sustained production of acid during the day and the even greater production of acid at night require intracellular sources. The present findings suggest that photoreceptor cells are the primary source of protons in the retina, because the lowest recorded $\mathrm{pH}_{\mathrm{o}}$ in the retina was in the vicinity of the inner segments of photoreceptor cells (Fig. 3), the location with the highest concentration of mitochondria in the retina. The present findings are thus consistent with the previous suggestion that photoreceptor cells are the principal consumers of energy in the retina (Haugh-Scheidt et al., 1995; Demontis et al., 1997). However, until a more thorough analysis of the sources and sinks of acid flux in the retina is performed, the present findings cannot be considered conclusive.

Although the clock-induced decrease in retinal $\mathrm{pH}$ at night likely reflects a clock-induced increase in retinal metabolic activity (Dmitriev et al., 1999a), the sequence of events whereby the clock affects $\mathrm{pH}$ and metabolic activity is not known. It is well known that ATP is used primarily to support electrochemical ionic gradients across the cell membrane, both in the brain (Astrup, 1982; Erecinska and Silver, 1989) and in the retina (Ames et al., 1992). The decrease in $\mathrm{pH}_{\mathrm{o}}$ and the increase in metabolic activity at night may be caused by clock-induced ionic conductance changes that result from the action of neurotransmitters such as melatonin (Cassone et al., 1988; Cosci et al., 1997) and dopamine (Shulman and Fox, 1996). In fact, recent evidence has shown that the potassium conductance of neurons in the suprachiasmatic nucleus (Pennartz et al., 1999) and pineal (Hasegawa and Dryer, 1999) is under circadian control. Alternatively, the clock may be directly increasing the activity of specific enzymes in retinal metabolic pathways at night.

\section{Location of the clock that regulates retinal $\mathrm{pH}$}

Our findings suggest that the clock that modulates retinal $\mathrm{pH}_{\mathrm{o}}$ is located in the rabbit retina itself. Specifically, we have demonstrated that the $\mathrm{pH}_{\mathrm{o}}$ of the in vitro rabbit retina changes from a daytime to a nighttime value when the retina is left in constant darkness and that this change occurs at dusk but not at other, nontransition times during the day and night (Fig. 4). Thus, our data suggest that an endogenous circadian clock in the in vitro rabbit retina produces a day/night difference in retinal $\mathrm{pH}_{\mathrm{o}}$. The clock that regulates retinal $\mathrm{pH}$ may be identical to the clock in the photoreceptor cells that regulates retinal melatonin synthesis (Cahill and Besharse, 1993). As noted above, clock-induced ionic conductance changes, which might result from the action of melatonin, may increase metabolic activity and decrease $\mathrm{pH}$ at night. However, it is also possible that the clock that regulates retinal $\mathrm{pH}$ is not the clock that regulates melatonin. It is interesting to note that cryptochrome genes, which may form part of the circadian clock, are expressed in the ganglion cell layer and inner nuclear layer (Miyamoto and Sancar, 1998) of the mouse, suggesting the possibility of a second clock in the retina.

Although it is very likely that the day/night difference in retinal $\mathrm{pH}_{\mathrm{o}}$ is caused by the action of a circadian clock, it is possible that a clock is not involved. We have shown that under conditions of constant darkness, the $\mathrm{pH}_{\mathrm{o}}$ of the rabbit retina is lower during the subjective night than in the subjective day (Figs. 1, 2). We have also shown that phase-shifting the light/dark cycle by $9 \mathrm{hr}$ phaseshifts the day/night difference in retinal $\mathrm{pH}_{\mathrm{o}}$ (Fig. 2). In addition, all of our data (Figs. 1-5) were obtained during the second cycle of constant darkness, demonstrating that the day/night difference in retinal $\mathrm{pH}$ persists for at least two $24 \mathrm{hr}$ cycles. Thus, our data indicate that a rhythmic process, which is likely a circadian clock, produces a day/night difference in retinal $\mathrm{pH}_{\mathrm{o}}$, persists for $2 \mathrm{~d}$, and can be entrained by light. However, because we do not know the period of this process and because we have not monitored the $\mathrm{pH}$ of an individual retina for at least $24 \mathrm{hr}$, it is theoretically possible that the daily rhythmic change in retinal $\mathrm{pH}_{\mathrm{o}}$ that is observed in constant darkness is not attributable to a circadian clock. That is, it is possible that the day/night difference in retinal $\mathrm{pH}_{\mathrm{o}}$ is an aftereffect of a rhythmic series of events brought about by daily exposure of the eye to a light/dark cycle. Such a $\mathrm{pH}$ rhythm might damp out in a few hours of darkness and not persist in a self-sustaining manner. On the other hand, because it has also been shown that a circadian clock with a period of $\sim 24 \mathrm{hr}$ regulates the $\mathrm{pH}$ of the fish retina (Dmitriev and Mangel, 2000), it is very likely that the rhythmic process that regulates $\mathrm{pH}$ in the rabbit retina is a circadian clock as well.

\section{Role of circadian clock regulation of retinal $\mathrm{pH}$}

Several lines of evidence suggest that a circadian clock-induced increase in the concentration of protons during the night may serve as a clock signal for the night. First, recent work has shown that the uncoupling action of dopamine on rabbit horizontal cells is $\mathrm{pH}$ dependent (Hampson et al., 1994). Although dopamine does not affect dye coupling between rabbit horizontal cells at a superfusate $\mathrm{pH}$ of 7.4 , it does uncouple the cells when the superfusate $\mathrm{pH}$ is reduced to 7.2. It is thus possible that a clock-induced decrease in retinal $\mathrm{pH}_{\mathrm{o}}$ at night allows dopamine to uncouple rabbit horizontal cells or that the low $\mathrm{pH}$ at night itself uncouples horizontal cells. Second, recent work has shown that a circadian clock regulates the light responses of fish and rabbit horizontal cells (Wang and Mangel, 1996; Mangel and Wang, 1997). Because of the action of the clock, the responses are cone mediated during the day and rod mediated, slower, and smaller in size during the night. A decrease in Ringer's solution $\mathrm{pH}$ from 7.6 to 7.4 , which reduces retinal $\mathrm{pH}_{\mathrm{o}}$ by $\sim 0.1 \mathrm{pH}$ units, an amount comparable to the extent of circadian regulation, reduces the size of fish horizontal cell light responses by $\sim 50 \%$ (Harsanyi and Mangel, 1993; Dmitriev and Mangel, 2000). A decrease in retinal $\mathrm{pH}_{\mathrm{o}}$ may reduce cone horizontal cell light responses by decreasing transmitter release from cones (Barnes et al., 1993). Thus, the clock-induced decrease in retinal $\mathrm{pH}_{\mathrm{o}}$ during the night may contribute to the suppression of horizontal cell light responses observed during the night. Circadian clock regulation of the $\mathrm{pH}_{\mathrm{o}}$ and metabolic activity of the retina may therefore modulate synaptic transmission in the retina. The clock-induced decrease in retinal $\mathrm{pH}_{\mathrm{o}}$ during the night may also increase rod photoreceptor sensitivity by stabilizing rhodopsin (Barlow et al., 1993). Studies that have used 2-deoxyglucose to measure metabolic activity have indicated that a circadian clock also regulates metabolic activity in the suprachiasmatic nucleus (Schwartz and Gainer, 1977). 
Thus, it is possible that circadian clock regulation of $\mathrm{pH}$ and metabolic activity is a general property of neural circadian clock tissue.

In summary, a circadian clock, which is probably located in the rabbit retina itself, regulates retinal $\mathrm{pH}$ so that the $\mathrm{pH}_{\mathrm{o}}$ is lower at night than in the day. Photoreceptor cells may serve as the primary source of the protons. The clock-induced shift in $\mathrm{pH}_{\mathrm{o}}$, which is likely caused by an increase in energetic metabolism at night, is several times greater than light-induced $\mathrm{pH}_{\mathrm{o}}$ changes. Finally, the circadian clock-induced increase in the concentration of protons during the night may serve as a clock signal for the night whereby neuronal signaling and coupling are modulated. Thus, an intrinsic oscillator in neural tissue modulates metabolic activity and $\mathrm{pH}$ as part of normal daily function.

\section{REFERENCES}

Alberti K, Cuthbert C (1982) The hydrogen ion in normal metabolism: a review. In: Metabolic acidosis (Porter R, Lawrenson G, eds), pp 1-19. Bath, UK: Pitman.

Ames III A, Ying-Ying L, Heher EC, Kimble CR (1992) Energy metabolism of rabbit retina as related to function: high cost of $\mathrm{Na}+$ transport. J Neurosci 12:840-853.

Astrup J (1982) Energy-requiring cell functions in the ischemic brain. J Neurosurg 56:482-497.

Barlow RB, Birge RR, Kaplan E, Tallent JR (1993) On the molecular origin of photoreceptor noise. Nature 366:64-66.

Barnes S, Merchant V, Mahmud F (1993) Modulation of transmission gain by protons at the photoreceptor output synapse. Proc Natl Acad Sci USA 90:10081-10085.

Block GD, Khalsa SB, McMahon DG, Michel S, Guesz M (1993) Biological clocks in the retina: cellular mechanisms of biological timekeeping. Int Rev Cytol 146:83-144.

Borgula GA, Karwoski CJ, Steinberg RH (1989) Light-evoked changes in extracellular $\mathrm{pH}$ in frog retina. Vision Res 29:1069-1077.

Cahill GM, Besharse JC (1993) Circadian clock functions localized in Xenopus retinal photoreceptors. Neuron 10:573-577.

Cahill GM, Besharse JC (1995) Circadian rhythmicity in vertebrate retinas: regulation by a photoreceptor oscillator. Prog Ret Eye Res 14:267.

Cassone VM, Roberts MH, Moore RY (1988) Effects of melatonin on 2-deoxy-14C-glucose uptake within rat suprachiasmatic nucleus. Am J Physiol 255:R332-R337.

Chesler M, Kaila K (1992) Modulation of $\mathrm{pH}$ by neuronal activity. Trends Neurosci 15:396-402.

Cosci B, Longoni B, Marchiafava PL (1997) Melatonin induces membrane conductance changes in isolated retinal rod receptor cells. Life Sci 60:1885-1889.

Demontis GC, Longoni B, Gargini C, Cervetto L (1997) The energetic cost of photoreception in retinal rods of mammals. Arch Ital Biol 135:95-109.

Dmitriev AV, Mangel SC (2000) A circadian clock regulates the $\mathrm{pH}$ of the fish retina. J Physiol (Lond) 522:77-82.

Dmitriev AV, Nagy TR, Mangel SC (1999a) A circadian clock regulates the metabolic activity of the fish retina. Invest Ophthalmol Vis Sci [Suppl] 40:S611.

Dmitriev AV, Pignatelli A, Piccolino M (1999b) Resistance of retinal extracellular space to $\mathrm{Ca}^{2+}$ level decrease: implications for the synaptic effects of divalent cations. J Neurophysiol 82:283-289.

Erecinska M, Silver I (1989) ATP and brain function. J Cereb Blood Flow Metab 9:2-19.

Hampson ECGM, Weiler R, Vaney DI (1994) pH-gated dopaminergic modulation of horizontal cell gap junctions in mammalian retina. Proc R Soc Lond B Biol Sci 255:67-72.

Harsanyi K, Mangel SC (1993) Modulation of cone to horizontal cell transmission by calcium and $\mathrm{pH}$ in the fish retina. Vis Neurosci 10:81-91.

Hasegawa Y, Dryer SE (1999) Diurnal modulation of K+ channels in chick pineal cells. Soc Neurosci Abstr 25:351.

Haugh-Scheidt LM, Griff ER, Linsenmeier RA (1995) Light-evoked oxygen responses in the isolated toad retina. Exp Eye Res 61:73-81.

Kraig RP, Ferreira-Filho CR, Nicholson C (1983) Alkaline and acid transients in cerebellar microenvironment. J Neurophysiol 49:831-850.

Krebs H, Woods H, Alberti K (1975) Hyperlactataemia and lactic acidosis. Essays Med Biochem 1:81-103.

Lavail MM, Ward PA (1978) Studies on the hormonal control of circadian outer segment disc shedding in the rat retina. Invest Ophthalmol Vis Sci 17:1189-1193.

Mangel SC, Wang Y (1997) Light responses of rabbit cone-connected horizontal cells exhibit a diurnal rhythm. Invest Ophthalmol Vis Sci [Suppl] 38:S616.

Mellergard P, Siesjo BK (1998) Cerebral energy metabolism and $\mathrm{pH}: \mathrm{pH}$ and brain function (Kaila K, Ransom BR, eds), pp 67-91. New York: Wiley-Liss.

Miyamoto Y, Sancar A (1998) Vitamin B2-based blue-light photoreceptors in the retinohypothalamic tract as the photoactive pigments for setting the circadian clock in mammals. Proc Natl Acad Sci USA 95:6097-6102.

Oakley B, Wen R (1989) Extracellular pH in the isolated retina of the toad in darkness and during illumination. J Physiol (Lond) 419:353-378.

Pennartz CMA, De Jeu MTG, Geurtsen AMS, Schaap J, Bos NPA (1999) Ionic mechanisms underlying the circadian rhythm in firing rate of rat suprachiasmatic nucleus. Soc Neurosci Abstr 25:2065.

Reme C, Wirz-Justice A, Terman M (1991) The visual input stage of the mammalian circadian pacemaking system: I. Is there a clock in the mammalian eye? J Biol Rhythms 6:5-29.

Schwartz W, Gainer JH (1977) Suprachiasmatic nucleus: use of 14Clabeled deoxyglucose uptake as a functional marker. Science 197:1089-1091.

Shulman LM, Fox DA (1996) Dopamine inhibits mammalian photoreceptor $\mathrm{Na}+, \mathrm{K}+$-ATPase activity via a selective effect on the alpha3 isozyme. Proc Natl Acad Sci USA 93:8034-8039.

Tosini G, Menaker M (1996) Circadian rhythms in cultured mammalian retina. Science 272:419-421.

Wang Y, Mangel SC (1996) A circadian clock regulates rod and cone input to fish retinal cone horizontal cells. Proc Natl Acad Sci USA 93:4655-4660.

Wirz-Justice A, Da Prada M, Reme CE (1984) Circadian rhythm in rat retinal dopamine. Neurosci Lett 45:21-25.

Yamamoto F, Borgula GA, Steinberg RH (1992) Effects of light and darkness on $\mathrm{pH}$ outside rod photoreceptors in the cat retina. Exp Eye Res 54:685-697. 